\title{
Benefits of Industry 4.0 for Logistics and Decision-making of Managers
}

\author{
Gabriel Koman $^{1}$, Milan Kubina ${ }^{1}$, Oliver Bubelíny ${ }^{1}$ and Marie Gabryšová ${ }^{2}$ \\ ${ }^{1}$ University of Žilina, Faculty of Management science and Informatics, Univerzitná 8215/1, Žilina, \\ Slovak Republic; Email: gabriel.koman@fri.uniza.sk, milan.kubina@fri.uniza.sk, \\ oliver.bubeliny@fri.uniza.sk \\ ${ }^{2}$ Katowice Business University, ul. Harcerzy-Wrzesnia 3, Katowice, Poland; Email: \\ marie.gabrysova@gwsh.pl
}

\section{*Corresponding Author: Jakub Soviar}

Abstract: The article discusses the benefits of the implementation of the Industry 4.0, focusing on the logistics management and decision-making of business managers. The obtained data and conclusions are evaluated qualitatively. Modern technologies have a significant impact on the lives of people and businesses today. This trend is mainly supported by advances in information and communication technologies. ICT technologies are now more accessible and smarter than ever before. This creates new opportunities and opportunities to improve business processes at enterprise level. ICT potential is also an option to generate more data thanks to devices and sensors in Industry 4.0. This data has a potentially important information value for the pony, especially in the decisionmaking process. The Industry 4.0 has been able to digitize the enterprise through several new technologies and their interconnection. Following the results obtained from this research study, it can be concluded that, based on acquired information through such a digital concept, Industry 4.0 can improve logistics and decision-making processes, and ultimately, the overall performance and prosperity of the enterprise. The Industry 4.0 is now creating an opportunity for businesses to digitize business operations at all levels of management.

Keywords: Logistics processes, Industry 4.0, management, benefits, decision-making

\section{Introduction}

The introduction of new IT technologies in society and companies is one of five megatrends according to global consultant companies. The biggest boom is assumed to be around 2020 to 2030 . The most extensive changes in SMART companies are Cloud computing, Digital Twin or Internet of Things (IoT) which belong to the Industry 4.0 (I 4.0) segment. The implementation of these technologies is important for employees and managers in the company. The benefits of deployment 
I 4.0 affect various aspects of the company. Leadership appreciates in particular process optimization, lower costs, etc. The purpose of the article is to justify the positive impact of also 4.0 on corporate decision-making, management and overall operational activities, while setting barriers and implementation problems.

\section{Methodology}

The information provided in the article has been obtained through methods of information retrieval, processing information and evaluating information. To obtain information, the method of document analysis was used, which was focused on obtaining data from articles and statistics of consulting companies. The data were processed by methods of comparison and deduction. Conclusions from the analysis were then formulated by induction. In the selection of the documents analyzed, these documents had to meet several criteria. Otherwise, they were not included in the analysis. The criteria for inclusion in the analysis were as follows:

- Orientation on Industry 4.0.

- Orientation on the management area.

- The documents were not studied before 2015. This is because the area of information and communication technologies is in a dynamic environment that is subject to constant change. Older document sources would not be the substance of analysis.

- Focus on using Industry 4.0 in Slovakia.

Further data were obtained from secondary sources, i.e. case study. The main source of this information due to their nature was the Internet, namely the website of solutions providers for Industry 4.0, annual reports and product catalogs. In order to be included in the analysis, the case study had to contain numerical expressions of improvement of activities. This was followed by a case study. Logic and creativity were used to formulate recommendations and conclusions.

\section{Industry 4.0}

Industry 4.0, respectively, the fourth industrial revolution is mainly focused on the issue of Smart manufacturing, followed by the previous phases - revolution (1. steam, 2. electricity, 3. automation). The main goal of Industry 4.0 is to transform businesses into a digital form that would be compatible with industrial IoT elements.

Industry 4.0 represents the next phase of production systems, which are enriched by an integrated set of technologies that adds value to the entire life cycle of the product [1]. It is a total transformation of processes using intelligent engineering and digitization [2]. The concepts of 
cybernetic-physical systems (CPS), the Internet and future-oriented technologies and intelligent systems with improved human-machine paradigms are applied within this concept [3].

The main elements of the Industry 4.0 concept include global trends, ICT, artificial intelligence, robotics, automation, intelligent manufacturing, logistics, customs computing, etc. According to Sanders et al. (2016) is one of the elements of the Industry 4.0 human (human factor) despite the possibilities of automation and artificial intelligence. Devices and sensors can collect data and transforming it into data, facilitating control and decision making, but ultimately the resulting variant is selected and implemented by the manager.

According to Čierny (2017), the main features of the Industry 4.0 concept include the following [4]:

- Customization of products and their continuous digitization.

- Implementation of autonomous devices in the enterprise (drones, trolleys, etc.).

- Searching and using of alternative sources due to environmental pollution and scarce resources.

- The growth of competitiveness in the market (technology represents a competitive advantage)

- Support for innovative activities.

According to the Mechanical Engineering Department in India, the main elements of digitization within the Industry 4.0 concept are technologies such as [5]:

- Internet of Things,

- Industrial Internet of Things,

- Cloud computing,

- Smart manufacturing.

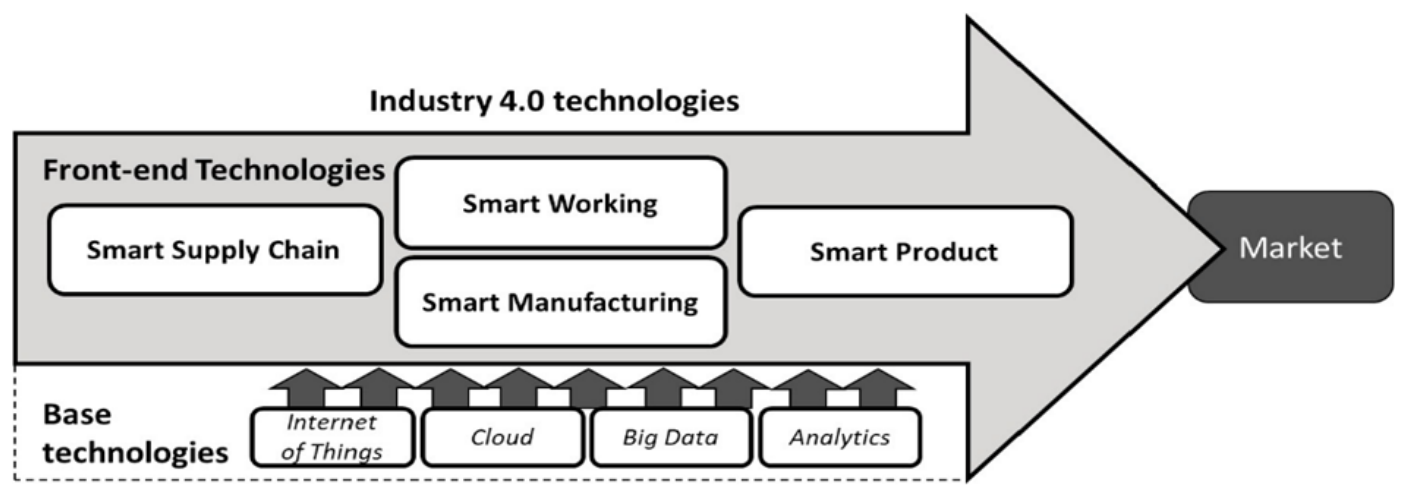

Fig 1 Structure of Industry 4.0. Source: [1]

These technologies are implemented in Industry 4.0 in two layers. The Front-end layer contains the so-called industry-leading applications, focused on value chain (production, logistics, work, production). The second, basic, layer contains classical technologies that ensure the distribution of 
data to a higher level. The combination of this data is obtained by the information needed to manage the market. This concept is illustrated in the following figure [1].

\section{Industry 4.0 Providers and Implementation Case Studies}

Siemens, GE, Microsoft and PTC are among the top four Industry 4.0 solution providers. The product portfolio that underpinned the use cases is shown in the following table [6]. The Industry 4.0 solutions providers are listed in the following table.

Table 4 Industry 4.0 platform providers. Source: [7-13]

\begin{tabular}{ccc}
\hline Company & Products & Area/focus \\
\hline Siemens & NX, Teamcenter, Simcenter, Tecnomatix, & Mechanical design, software engineering, \\
& MindSphere, PLM components, Polarion, \\
& Mentor, centre for manufacturing & simulations and tests, production \\
operations, Solid Edge, TIA Portal, & planning, automation \\
Mendix & \\
\hline GE & digital twin, prediction of production and & company digital transformation \\
& maintenance, Cloud services, & \\
\hline Microsoft & cybersecurity & smart manufacturing \\
\hline PTC & AI, IIoT, CAD, PLM, Cloud & company digital transformation \\
\hline
\end{tabular}

The worldwide PwC survey in 2016 shows that up to $21 \%$ of respondents use Industry 4.0 technology in production [14].

\subsection{Case Study - GE Digital}

Gallo Glass specializes in glass packaging for bottles produced in continuous production on 14 lines. Initial problem - poor product quality, repetitive errors and device downtime, which negatively impacted labor productivity and total sales. Solution - System for monitoring and control system - Predix HMI/SCADA from GE Digital. Implementation effect - ranking in the InformationWeek Top 500, reducing downtime and errors by $25 \%$, improving quality and productivity by 5\%, profit growth of $\$ 5$ million, optimizing logistics costs, reliable and environmentally friendly production contribute to Gallo Glass's competitive advantage. Benefits Predix can collect and analyze data from furnaces, bottle labels and stores, information distributed 
to facilities from operators to managers, covering operational, tactical and strategic level - reporting via the web [15].

\subsection{Case Study - Siemens}

Akevono Kohgyo is a Japanese company that implemented Siemens NX system to shorten the setup time of automotive components machines. Solution - digitization of all activities, from preparation, design to production, quality control and decision support. Benefits - real-time device setup, order increase, data analysis and processing have been reduced by $70 \%$, process optimization by $80 \%$ [16].

\subsection{Case Study - Microsoft}

The Textron global company has eight divisions and 32000 employees. The problem has increased the cost of an unacceptable level in holding all relevant data. Solution - Microsoft Azure, use cloud storage. Benefit - Annual cost reduction of 2.5 million, optimal scalability, manager can view data within a few minutes [17].

\subsection{Case Study - PTC}

The new trend in the Industry 4.0 and technology has become the concept of a 3D printer. The 3D Systems Company integrates three-dimensional printing together with IoT. Problem - no monitoring of equipment, such as nitrogen or heat values. Solution - Thinkworx platform, collects data from I4.0. Benefit - printer diagnostics regardless of distance, improved service, reporting, high return on investment, faster error resolution, less downtime, maintenance teams are not sent to the field as often to optimize business $[10,14]$.

\section{Benefits from Industry 4.0 Implementation for Operation and Decision Making of Managers}

The implementation of Industry 4.0 creates a competitive advantage for businesses. According to the PTC company (the solution provider in the area), the concept brings lower operating costs, fewer downtime, higher productivity, security, optimal asset utilization, products meet customer requirements (quality) and flexibly responds to dynamic environmental changes. The PwC survey Global Industry Survey examined the implications of I 4.0 implementation and expectations of approx. 2,000 managers operating in 26 countries around the world [14,18-21].

Benefits of implementing Industry 4.0 for company management are as follows [14,21]:

- annual cost reduction of $3.6 \%$,

- revenue growth of $2.9 \%$ (1 year after implementation), 
- better CRM system,

- revenue growth of $30 \%$ by 2020 ,

- personalized products,

- predictive maintenance, equipment performance growth,

- vertical and horizontal integration in production and logistics,

- optimizing business processes through automation and digitization,

- customer-oriented marketing,

- innovation - the development of digital products,

- customers are given a higher value for which they are willing to pay more because the benefits outweigh the costs,

- global connectivity, easier data sharing worldwide,

- competitive advantage,

- order growth,

- quality service,

- return on investment (comparison of indicator values before and after the introduction of Industry 4.0).

Benefits of implementing Industry 4.0. for support of decision making:

- real-time data acquisition,

- feedback within minutes,

- effective performance of management functions (planning, organizing, controlling),

- effective management at all levels in the company (strategic, tactical, operational),

- quality reporting, data directly from the terrain,

- enough scalability of data and information, increased storage capacity, access at any time (Cloud).

Possible barriers and limitations of Industry 4.0 implementation in the company are [14,21]:

- the willingness of employees to change,

- trainings,

- introduction of digital culture, adjustments in organizational structure,

- data security,

- complicated risk management,

- time and money-intensive (in the US, they invest approx. \$ 907 billion to develop digitization in the industrial world),

- extinction of some jobs - dissatisfied employees, dissemination of negative reputation, 
- interoperability and compatibility issues with current IS and new Industry 4.0 technologies, the need to introduce a new architecture, requires funding,

- reluctance of partners, e.g. suppliers to collaborate in digitization,

- uncertainty, return on investment is reflected min. after 2 years,

- managers often cannot sufficiently motivate employees into a common "digital" vision of the company.

Given these options and limitations, it is important that managers carefully plan the strategy for development of an ICT business, get an overview of the cases of use competition and prepare for all negative aspects. In a dynamic environment, it is necessary to adapt to the given conditions and use them for your benefit [22,23].

\section{Conclusion}

The global Trend Industry 4.0 is gradually shifting from abroad to Slovakia. The greatest technological boom is expected in 2020. The new concept changes the way we work, communicate and live. Sensors can collect data in real time and transfer them to huge distances over the Internet. Analysts in the company can not only retrieve this data in a matter of minutes, but also process it and send it to managers via an internal network. Business management turns data into information that makes management and decision making easier. The main advantages include process optimization, cost reduction and increased safety and productivity.

However, everything also has negative aspects. The main barriers to implementation of I 4.0 include the human factor. Technology is invented by people and is also used to make their lives easier. To successfully introduce innovation, it is necessary to change the mindset of employees, to provide training and to convey a vision of joint growth through digitization. There are currently many case studies from solution providers (e.g. Siemens, GE, Microsoft, PTC) in a given field, to foreign articles, which indicate the appropriate types of technological components and successful examples of implementation in practice. The 21 st century industry will only give a competitive edge to those who are well prepared, not afraid of risk, flexible and anticipating future options. Anyone who does not follow this trend and ignores it is destined to gradually disappear over time.

\section{Acknowledgments}

This publication was realized with support of the Operational Program Research and Innovation in frame of the project: ICT for smart society, code ITMS2014 +: 313011T462, co-financed by the European Regional Development Fund. 


\section{References}

[1] Frank, A.G., Dalanogare, L.S. \& Ayla, N.F. (2019). Industry 4.0 technologies: Implementation patterns in manufacturing companies. International Journal of Production Economics. 210(4), $15-26$.

[2] Castelo-Branco, I., Cruz-Jesus, F. \& Oliveira, T. (2019). Assessing Industry 4.0 readiness in manufacturing: Evidence for EU. Computers in Industry. 107(5), 22-32.

[3] Sanders, A., Elangeswaran, C. \& Wulfsberg, J. (2016). Industry 4.0 Implies Lean Manufacturing: Research Activities in Industry 4.0 Function as Enablers for Lean Manufacturing. Journal of Industrial Engineering and Management. 9(3), 811-833.

[4] Burieta, J. (2017). Prvý ročník fóra kvality bol vel'mi úspešný. Retrieved September 01, 2019, from https://www.ipaslovakia.sk/sk/tlac-a-media/aktualne-vzdelavanie/prvy-rocnik-forakvality-bol-velmi-uspesny.

[5] Vaidya, S., Ambad, P. \& Bhosle, S. (2018). Industry 4.0 - A Glimpse. Procedia Manufacturing. 20, 233-238.

[6] Wopata, M. (2019). IoT analytics - market insight. The leading Industry 4.0 companies 2019. Retrieved September 02, 2019, from https://iot-analytics.com/the-leading-industry-4-0companies-2019/.

[7] Microsoft Azure product portfolio. (2019). Retrieved September 02, 2019, from https://azure.microsoft.com/en-us/.

[8] Migalani, S. (2018). Microsoft - Industry 4.0, smart factories with IoT and AI. Retrieved September 10, 2019, from https://blogs.msdn.microsoft.com/msind/2018/04/27/iiot-smartfactories-ai-azure-iot-edge/.

[9] Müller, J. \& Däschle, S. (2018). Business Model Innovation of Industry 4.0 Solution Providers towards customer process innovation. Processes. 6(12), 260.

[10] PTC - augmented reality, use cases. (2019). Retrieved September 11, 2019, from https://www.ptc.com/-/media/Files/PDFs/IoT/J10118_PTC_AR_Use_Cases_ebk_EN_V4.pdf.

[11] Siemens - product portfolio for digital innovations. (2019). Retrieved October 05, 2019, from https://www.plm.automation.siemens.com/global/en/products/.

[12] WT1 - Production portfolio of GE Digital. (2019). [Retrieved October 16, 2019, from https://www.ge.com/digital/sites/default/files/download_assets/Become-digital-industrialcompany-GE-Digital-overview.pdf. 
[13] WT2 - Production portfolio of GE Digital second part. (2019). Retrieved October 20, 2019, from https://www.ge.com/digital/blog/industry-40-lets-get-started.

[14] PwC - Industry 4.0: Budovanie digitálneho podniku. (2019). Retrieved October 21, 2019, from https://www.pwc.com/sk/sk/publikacie/assets/2016/ceo-prieskum/industry-4-0budovanie-digitalneho-podniku.pdf.

[15] GE Digital - Use case Gallo Glass Company. (2019). Retrieved October 23, 2019, from https://www.ge.com/digital/customers/gallo-glass-company-improves-quality-safety-andefficiency-ifix-ge-digital.

[16] Siemens - case study of Akevono Kohgyo. (2019). Retrieved October 23, 2019, from https://www.plm.automation.siemens.com/pub/case-studies/64571?resourceId=64571.

[17] Microsoft - case study Textron. (2019). Retrieved October 23, 2019, from http://customers.microsoft.com/en-in/story/manufacturer-to-reduce-it-costs-by-25-millionwith-hyb.

[18] Solutions Industry 4.0 from PTC. (2019). Retrieved October 23, 2019, from https://www.ptc.com/en/industries/manufacturing.

[19] Falát, L. \& Holubčík, M. (2017). The influence of marketing communication on financial situation of the company - a case from automobile industry. Procedia Engineering. 192, 148153.

[20] Soviar, J., Holubčík, M., Rechtorík, M. \& Pollak, F. (2019). The Presentation of Automotive Brands in the On-Line Environment The Perspective of KIA, Peugeot, Toyota and VW in the Slovak Republic. Sustainability. 11(7), 2132.

[21] Soviar, J., Holubčík, M. \& Vodak, J. (2018). Regional Cooperation Ecosystem: Case of the Zilina Self-Government Region (Slovak Republic). Sustainability. 10(7), 2219.

[21] Holubčík, M. \& Falát, L. (2016). Possible implementations of prediction models for forming global cooperation relations. In Globalization and its socio-economic consequences - 16th international scientific conference, (pp. 670-677). Rajecke Teplice, Slovak Republic.

[22] Seetharaman, A., Patwa, N., Saravanan, A.S. \& Sharma, A. (2019). Customer expectation from industrial internet of things (IIOT). Journal of Manufacturing Technology Management. 30(8), 1161-1178. DOI: 10.1108/JMTM-08-2018-0278.

[23] Sevinç, A., Gür, S. \& Eren, T. (2018). Analysis of the difficulties of SMEs in industry 4.0 applications by analytical hierarchy process and analytical network process. Processes. 6(12) DOI: $10.3390 /$ pr6120264. 